NBER WORKING PAPER SERIES

\author{
PRICE, TOBACCO CONTROL \\ POLICIES AND YOUTH SMOKING
}

Frank J. Chaloupka

Michael Grossman

Working Paper 5740

\author{
NATIONAL BUREAU OF ECONOMIC RESEARCH \\ 1050 Massachusetts Avenue \\ Cambridge, MA 02138 \\ September 1996
}

This paper was presented at the Economics of Substance Abuse II session of the 71st annual conference of the Western Economic Association International, July 1, 1996, San Francisco, CA. Support for this research has been provided by the Robert Wood Johnson Foundation and the Centers for Disease Control and Prevention. We are indebted to Robert L. Ohsfeldt for his helpful comments, to John Taurus and Junji Zhang for their research assistance, and to Patrick O'Malley and Timothy J. Perry for providing the Monitoring the Future data. This paper is part of NBER's research program in Health Economics. Any opinions expressed are those of the authors and not those of the National Bureau of Economic Research.

(C) 1996 by Frank J. Chaloupka and Michael Grossman. All rights reserved. Short sections of text, not to exceed two paragraphs, may be quoted without explicit permission provided that full credit, including $(\mathbb{C}$ notice, is given to the source. 
NBER Working Paper 5740

September 1996

\title{
PRICE, TOBACCO CONTROL \\ POLICIES AND YOUTH SMOKING
}

\begin{abstract}
This paper examines the effectiveness of several tobacco control policies in discouraging cigarette smoking among youths. These policies include increased cigarette excise taxes (which result in higher cigarette prices), restrictions on smoking in public places and at private worksites, and limits on the availability of tobacco products to youths. The data employed in this research are taken from the 1992, 1993, and 1994 surveys of eighth, tenth, and twelfth grade students conducted by the University of Michigan's Institute for Social Research as part of the Monitoring the Future Project. Site specific cigarette prices and measures of tobacco related policies are added to the survey data. The results indicate that tobacco control policies can be effective in reducing youth cigarette smoking. The average overall estimated price elasticity of youth cigarette demand of -1.313 indicates that large increases in cigarette excise taxes would lead to sharp reductions in youth smoking. Similarly, strong restrictions on smoking in public places would reduce the prevalence of smoking among youths, while limits on smoking in schools would reduce average cigarette consumption among young smokers. However, limits on youth access to tobacco products appear to have little impact on youth cigarette smoking. This is most likely the result of the relatively weak enforcement of these laws.
\end{abstract}

Frank J. Chaloupka

Department of Economics (M/C 144)

University of Illinois at Chicago

601 South Morgan Street

Chicago, IL 60607-7121

and NBER

fjc@uic.edu
Michael Grossman

National Bureau of Economic Research 50 East 42nd Street, 17th Floor New York, NY 10017-5405

mgrossma@email.gc.cuny.edu 


\section{Introduction}

In the twenty years after the release of the first U.S. Surgeon General's report on the health consequences of cigarette smoking in 1964, considerable progress was made in reducing cigarette smoking in all segments of the population. From 1987 to 1990 , the downward trend in smoking participation among adults accelerated to an average rate double the rate of decline over the preceding 20 years (Institute of Medicine, 1994). This success was achieved with a variety of tobacco control policies, including the widespread dissemination of information on the health consequences of cigarette smoking, broadcast of anti-smoking advertisements, limits on tobacco advertising, restrictions on smoking in public places and private workplaces, increased cigarette excise taxes, and various others (USDHHS, 1989).

However, continued reductions in the prevalence of smoking among youths have not been sustained in recent years. As the recent Surgeon General's report notes (U.S. Department of Health and Human Services (USDHHS), 1994), smoking rates among youths fell sharply throughout the 1970's. However, during the 1980's and early 1990's, the percentage of youths who are regular smokers has remained relatively stable, with prevalence increasing in some youth populations (Centers for Disease Control and Prevention (CDC), 1994). These trends, coupled with the growing evidence on the addictive nature of cigarette smoking (USDHHS, 1988), have led to an increased emphasis on policies to discourage the use of tobacco among young people. These efforts include increasing (or establishing) the minimum legal purchase age for tobacco products, restricting the sale of cigarettes through vending machines, limiting the free distribution of cigarettes to underage youths, and others. Much of this legislation was 
developed at the local level, but with the Synar amendment, the Federal government has emphasized the importance of reducing the availability of tobacco to youths. This amendment requires states to clearly demonstrate that they are enforcing laws which prohibit the sale and distribution of all tobacco products to persons under eighteen years of age.

This paper examines the effectiveness of several tobacco control policies in discouraging cigarette smoking among youths. These policies include increased cigarette excise taxes (which result in higher cigarette prices), restrictions on smoking in public places and at private worksites, and limits on the availability of tobacco products to youths. The data employed in this research are taken from the 1992, 1993, and 1994 surveys of eighth, tenth, and twelfth grade students conducted by the University of Michigan's Institute for Social Research as part of the Monitoring the Future Project. This is a particularly interesting age group to study since it includes youths at a critical point in the initiation of regular smoking. As the recent Surgeon General's report concludes, almost all adult smokers first use cigarettes by high school graduation, while almost no first use occurs after age twenty. Thus, tobacco control policies which discourage cigarette smoking in this age group may be the most effective way of achieving long run reductions in smoking in all segments of the population.

\section{Selected Review of Econometric Studies of Cigarette Demand}

Numerous econometric studies of cigarette demand have been published over the past 
several decades. ${ }^{1}$ Most of these studies have used diverse data and methods to estimate the effects of cigarette prices and taxes on smoking participation and cigarette consumption in the overall population. One general conclusion emerges: increases in cigarette prices will significantly reduce cigarette consumption. A recent National Cancer Institute sponsored gathering of economists and other experts on the impact of cigarette prices on demand concluded that the overall price elasticity of cigarette smoking fell in the range from -0.3 to -0.5 ( $\mathrm{NCI}$, 1993a).

Relatively few of these econometric studies have used individual level data to focus on the price responsiveness of cigarette smoking among youths and young adults. The first significant work in this area was completed by Lewit and his colleagues in the early 1980's. Lewit and Coate (1982) estimate cigarette demand and smoking participation equations using the 1976 Health Interview Survey by age (20-25 years, 26-35 years, and 35-74 years) and gender. They find that the majority of the impact of price is on the decision to smoke rather than on the quantity smoked by smokers. In addition, they find that the smoking behavior of young adults (20-25 years) is more sensitive to price than that of older individuals. They estimate that the overall elasticity among those $20-25$ years is -0.89 , with a participation elasticity of -0.74 , as compared to their estimates of -0.42 and -0.26 , respectively, for all adults. Finally, they find that men, particularly those ages 20 to 35 years, are quite responsive to price, while cigarette smoking among women is unaffected by price.

Lewit, Coate, and Grossman (1981) used Cycle III of the Health Examination Survey

${ }^{1}$ For comprehensive reviews of these studies, see the 1989, 1994, and forthcoming Surgeon General's reports (USDHHS 1989, 1994, forthcoming) 
(HES-III) conducted from March 1966 through March 1970, to look at the effects of cigarette prices, the negative cigarette advertising under the Fairness Doctrine, and various socioeconomic and demographic factors on cigarette smoking among 12 to 17 year olds. They estimate smoking participation equations for all youth as well as cigarette demand equations for youth smokers. This allows them to distinguish the effect of price on the decision to smoke from its impact on cigarette consumption by smokers. They estimate that the price elasticity of demand among youths is -1.44 , more than three times as high as it is among adults, and nearly double that of young adults (ages 20 through 25 years), when comparing their estimates to those of Lewit and Coate (1982). They find a strong impact of price on the decision to smoke (price elasticity of -1.20 ) rather than on average consumption by smokers (price elasticity of -0.25 ) These findings are generally confirmed in a related study by Grossman, et al., (1983) which uses the 1974, 1976, 1977, and 1979 National Surveys on Drug Abuse. They note that estimates from this study should be interpreted cautiously since sample sizes are relatively small. In general, they find that the decision to smoke is negatively related to price, with their summary estimate of this elasticity as -0.76 . Again, this estimate is substantially higher, in absolute value, than that obtained for adults by Lewit and Coate, implying that the decision to smoke by youths is much more responsive to price than the comparable decision for adults. However, they find that, once the decision to smoke has been made, average consumption decisions by youth smokers are virtually unresponsive to price.

Warner (1985) uses the age specific price elasticities of participation and demand from Grossman and his colleagues to obtain comparable estimates for teenagers ages 18 to 19 . He predicts that the 1983 doubling of the Federal excise tax reduced the number of teenage smokers 
by 800,000 . These estimates are the basis for a General Accounting Office report (1989) concluding that an increase in the Federal tax to 20 cents per pack in 1989 would have cut the number of teenage smokers by an additional 500,000. The GAO predicts a subsequent reduction of 125,000 smoking related deaths for this age group as a result of the proposed 20 cent tax increase. Similarly, based on the work by Grossman and his colleagues, Harris (1987) concludes that the 1983 doubling of the Federal cigarette tax, and the coordinated price increases it induced, kept 600,000 teenagers, from starting to smoke.

More recently, Chaloupka (1991) estimated the price elasticity of cigarette demand for youths and young adults (ages 17 through 24) in the context of the Becker and Murphy (1988) model of rational addictive behavior. Rationality, in this context, implies that the future consequences of smoking are considered when making current choices. Using data from the National Health and Nutrition Examination Survey II (NHANESII), Chaloupka finds that price increases significantly reduce cigarette consumption and that their impact is understated if addiction is ignored. In addition, he finds that less educated (younger) individuals behave more myopically than more educated (older) individuals, while more addicted (myopic) individuals are more responsive to price in the long run than their less addicted (myopic) counterparts. Youths and young adults (ages 17 to 24) are found to be less responsive to price than older groups. Chaloupka finds that women act less myopically and are less responsive to price than men. Finally, he finds that restrictions on smoking in public places have a significant negative impact on average cigarette consumption.

Wasserman, et al. (1991) use several of the Health Interview Surveys from the 1970's and 1980 's to examine changes in the price elasticity of demand over time. They find that the 
negative impact of cigarette prices on cigarette demand for adults has increased over time. In addition, they use data on youths ages 12 through 17 years taken from NHANESII to look at the impact of prices and smoking restrictions on youth smoking. Wasserman, et al.'s findings for youths contradict the general conclusion of Grossman and his colleagues that youth cigarette smoking is more responsive to price than is adult smoking. Wasserman and his colleagues estimate a statistically insignificant effect of cigarette prices on average cigarette consumption among all youths, youth smoking participation, and cigarette consumption by young smokers. Given their estimates, they cannot reject the hypothesis that the price elasticity of demand for teenagers is statistically different from their estimate for adults. Wasserman, et al., suggest that one of the reasons for their relatively low estimate is their inclusion of an index capturing antismoking regulations as a determinant of demand. They find that these regulations, generally excluded as explanatory variables in earlier studies of demand, are highly correlated with cigarette prices. They argue that the price effects estimated in other studies may be biased upwards since prices are also picking up the effects of the anti-smoking regulations. They do estimate that these anti-smoking regulations have a large negative effect on cigarette smoking by youths, and that the regulations are most effective in preventing youths from initiating smoking.

Grossman (1991) notes, however, that the estimates by Wasserman, et al., while an important contribution, should not be considered the definitive estimates of the price elasticity of demand, particularly for youths. As Wasserman, et al. indicate, part of the reason for their relatively low estimates is the inclusion of the regulation index, which is highly correlated with price. Others, including Chaloupka (1991, 1992), Chaloupka and Saffer (1992), and Chaloupka 
and Wechsler (1995), do not find that the estimated price elasticity of demand is sensitive to the inclusion of measures of these anti-smoking regulations. Furthermore, including the regulation index may be inappropriate in their teenage sample, since it assumes its highest value in states restricting smoking in private worksites. This restriction is unlikely to have any direct impact on youths since they spend most of their time in school. If the regulations themselves have no impact on smoking, but are instead proxies for anti-smoking sentiment, then enacting very restrictive measures will not necessarily reduce youth smoking. Finally, Grossman suggests that Wasserman, et al.'s findings for their relatively small sample of youths $(1,891)$ should be interpreted cautiously when compared to those obtained by Lewit, Coate, and Grossman (sample size 5,308$)$.

More recently, Evans and Farrelly (1995) pooled data from 13 of the National Health Interview Surveys conducted from 1976 through 1992 to examine the demand for cigarettes by young adults (ages 18 through 24 years) and adults (ages 25 through 39 years and ages 40 and older). Their findings are consistent with the earlier work by Lewit and Coate (1982) in that they find that the price responsiveness of cigarette demand decreases with age. The estimate an overall price elasticity of demand of -0.63 for young adults, approximately fifty percent higher than the -0.42 they estimate for those ages 25 through 39 . Moreover, they find no significant effect of price on either smoking participation or average daily cigarette consumption for their oldest sample (40 years and older). In addition, Evans and Farrelly examine the potential for substitution towards higher tar and nicotine cigarettes in response to increased prices. They do find this type of price induced compensating behavior, with shifts for young adults large enough to actually increase tar and nicotine consumption among continuing smoker after a price 
increase, offsetting some of the potential health benefits associated with higher taxes.

Most recently, Chaloupka and Wechsler (1995 and forthcoming) looked at the effects of prices and restrictions on cigarette smoking among college students, using data taken from the 1993 Harvard College Alcohol Study. Their sample includes 16,277 students in 140 U.S. colleges and universities. Chaloupka and Wechsler's findings are consistent with the research by Lewit and his colleagues. Their estimates of the price elasticity of demand for cigarettes among college students center on -1.11, with an estimated elasticity of smoking participation of 0.53. In addition, they find that relatively stringent restictions on smoking in public places significantly reduce the likelihood that college students smoke, while any restrictions on smoking lead to reductions in the quantity smoked by smokers.

While numerous studies of the effects of price on cigarette smoking have been completed in recent years, a small number of which also examine the impact of clean indoor air laws on smoking, the impact of other policies related to cigarette smoking, particularly among youths and young adults, have not been examined using large, nationally representative data. However, several studies may shed some light on the effectiveness of these policies in discouraging youth smoking and other tobacco use.

DiFranza, et al., (1987) find that minimum purchase age laws have little success in reducing minors' access to tobacco since the laws are poorly enforced. They suggest that prohibitions on tobacco possession by minors, warning signs at the point of sale, and bans on vending machines sales could be more effective. Jason, et al., (1991), in their study of Woodridge, IL, find that youth smoking fell significantly in the city in response to the aggressive enforcement of a law restricting cigarette sales to minors. Forster, Hourigan, and Kelder 
(1992), in their examination of St. Paul, MN, find that bans on the sale of cigarettes through vending machines are likely to be more effective in reducing youth access to cigarettes than requiring locking devices on the machines, since this requirement needs additional enforcement to ensure compliance. Altman, et al., (1991) find that community wide educational efforts in Santa Clara County, CA, had sustained success in reducing youth smoking, although some recidivism occured.

To summarize, the effect of cigarette prices on smoking by youths and young adults is unclear, although increased prices are expected to reduce their smoking by at least as much as they do among adults. Similarly, little is known about the impact of clean indoor air laws on youth and young adult smoking. Finally, the effects of limits on youth access to tobacco, including minimum purchase age laws, restrictions on vending machine sales, and others have not been examined empirically in large, nationally representative data. This research addresses these issues by studying the impact of cigarette prices, restrictions on smoking in public places, limits on youth access to tobacco, and related policies on smoking participation and average daily cigarette consumption in a large, nationally representative sample of eighth, tenth, and twelfth grade students.

\section{Data and Methods}

The data for this study are taken from the 1992, 1993, and 1994 surveys of eighth, tenth, and twelfth grade students conducted by the Institute for Social Research (ISR) at the University of Michigan as part of the Monitoring the Future Project. Every year since 1975, ISR has 
collected a nationally representative sample of 15,000 to 19,000 high school seniors. In 1991, an annual survey of similar numbers of eighth and tenth grade students was added. These surveys, described in detail by Johnston, O'Malley and Bachman (1993) focus on the use of alcohol, tobacco, and illicit drugs among youths. Given the nature of the data being collected, extensive efforts are made to ensure that the data collected are informative. Parents, for example, are not present during the completion of the survey and are not informed about their child's responses. By special agreement, a restricted data set with variables reflecting youth tobacco use and identifiers for each youth's county of residence was provided. These data also include a variety of socioeconomic and demographic information.

All respondents were asked about their recent cigarette smoking. ${ }^{2}$ Two alternative measures of youth cigarette smoking are constructed from the information collected in the surveys. $^{3}$ The first measure is a dichotomous indicator of smoking participation equal to one for youths who report any cigarette consumption in the past thirty days, and equal to zero otherwise. In addition, based on the midpoints of the categorical responses reflecting average daily cigarette consumption, a "continuous" measure of daily cigarette consumption was constructed. ${ }^{4}$ While not ideal, this continuous measure will be helpful in developing estimates of the price elasticity of cigarette demand among young smokers.

${ }^{2}$ Unfortunately, the surveys did not collect the detailed data on past cigarette smoking needed to estimate demand equations applying the Becker and Murphy (1988) or other economic models of addictive behavior.

${ }^{3}$ Average daily cigarette consumption is reported in seven categories for youths indicating that they are current smokers.

${ }^{4} \mathrm{~A}$ value of 45 was assigned to the open ended category ( 2 or more packs per day). Alternative values were also used with no appreciable impact on the estimates. These results are available upon request. 
Based on the survey data, a variety of independent variables were constructed to control for other factors affecting cigarette demand. These include: the age of the respondent, in years; average weekly income from all sources (employment, allowances, and other sources); an indicator for males; indicators for youths surveyed in 1993 and 1994; an indicator for youths surveyed in the eighth/tenth grade survey; indicators of race/ethnicity (Black, and other nonWhite); an indicator for married or engaged youths; indicators of parental education (less than high school graduate, and more than high school graduate for mother and father separately); indicators of family structure (live alone, mother only parent present, father only parent present, no parent present - live with other(s)); indicators of mother's work status while youth was growing up (mother worked part-time and mother worked full-time); an indicator for youths with siblings; average number of hours worked weekly; an indicator for youths living in rural areas; and indicators for frequency of participation in religious services (infrequent participation and frequent participation).

Based on each respondent's county of residence, cigarette price and tobacco control policy data were added to the survey data. The measure of cigarette price is a state level average cigarette price taken from the Tobacco Institute's annual Tax Burden on Tobacco. This price measures is inclusive of state level excise taxes on cigarettes and reflects the average price for a pack of twenty cigarettes, based on the prices of single packs, cartons, and vending machine sales, and includes generic cigarettes. ${ }^{5}$ To account for changes in relative prices

5 Two additional price series were added to the survey data. The first is also a state level average cigarette price taken from the Tax Burden on Tobacco, but which excludes generic cigarettes. The second is a city specific price taken from the American Chamber of Commerce Researchers' Association's quarterly Inter-City Cost of Living Index and reflects the price of a carton of Winston king-size cigarettes. The three price variables are highly correlated and 
between 1992 and 1994, the cigarette price, as well as weekly income, was deflated by the National Consumer Price Index for the first two quarters of the survey year.

A set of tobacco control policy variables was added to the surveys based on each youth's county of residence. These variables include measures of state, county and city level restrictions on cigarette smoking in public places and private workplaces and limits on the availability of tobacco products to youths. The restrictions on smoking are captured by a set of five variables indicating the fraction of the population in each youth's county of residence subject to restrictions on smoking in private workplaces, restaurants, retail stores, schools, or any other place.

Limits on the availability of tobacco products to youths are measured by several variables including: the state minimum legal purchase age for cigarettes, an indicator for youths residing in states requiring signs to be posted reflecting the minimum legal purchase age, and variables reflecting the fraction of the population in each youth's county of residence with restrictions on the sale of tobacco products through vending machines, the fraction in counties limiting the distribution of free samples of tobacco products, and the fraction in counties requiring licensing of those who sell tobacco products.

Finally, two additional measures of state tobacco related policies are included. The first is a dichotomous indicator equal to one for states which earmark a portion of the tax revenues

produced very similar estimates.

The Tobacco Institute reports prices as of November 1 each year. To obtain an estimate of the price in the first two quarters of the survey year, since the surveys are conducted in the spring, the November 1 price, exclusive of state and federal taxes was computed for the survey year and the previous year. Monthly prices, exclusive of taxes, were estimated based on a linear interpolation. Average taxes were then added to the average price for the first two quarters of each year. 
generated by state cigarette excise taxes for other tobacco control activities (including antismoking media campaigns), and equal to zero otherwise. The second is an indicator equal to one for states which have adopted some form of smoking protection legislation, and equal to zero otherwise.

Data on state level tobacco control policies were taken from the Coalition on Smoking OR Health's (CSH) annual State Legislated Actions on Tobacco Issues. Similar information on county and city level restrictions was taken from the NCl's (1993b) monograph summarizing major local tobacco control policies, updated with information from CSH.

After eliminating respondents with missing or inconsistent data, a sample of 110,717 youths was obtained. Table One contains descriptive statistics for the dependent and independent variables employed.

Given the limited nature of the dependent variables, ordinary least squares techniques are inappropriate. Instead, a two-part model of cigarette demand is also estimated based on the model developed by Cragg (1971). In these specifications, probit methods are used to estimate a smoking participation equation in the first step. In the second step, least squares methods are used to estimate average daily cigarette consumption by smokers, where the dependent variable is the natural logarithm of the continuous average daily consumption measure. The same set of independent variables is included in both equations.

\section{Results}

Estimates of the two-part model for youth cigarette demand are contained in Tables Two 
and Three. Given the large number of policy variables and the high correlations among many of these variables, two alternative strategies were pursued in estimating the two-part model. In the first strategy, smoking participation and conditional cigarette demand equations which contain all socioeconomic and demographic variables, the real cigarette price, and at most one tobacco related policy variable are estimated. The estimates for the policy and price variables obtained from this strategy are contained in Table Two. ${ }^{6}$ Each row in Table Two presents the coefficients and t-ratios from the two-part model for cigarette price and the tobacco control policy variable contained in that specification. Including only a single tobacco control policy variable in each specification of the two-part model minimizes the multicollinearity resulting from the inclusion of a large number of highly correlated variables. Omitting the other policy variables, however, may lead to biased estimates of the effects of cigarette prices and the included policy variable on youth cigarette demand. The second estimation strategy addresses this possibility by including all tobacco related policy measures as independent variables in the smoking participation and conditional cigarette demand equations. The estimates for the full set of policy variables, cigarette price, and all socioeconomic and demographic variables are presented in Table Three. In these specifications, the omitted variables bias is minimized However, including the large set of policy variables may result in multicollinearity, making it difficult to estimate the true impact of these policies on youth cigarette smoking.

\section{a. Tobacco Related Policy Variables}

\footnotetext{
${ }^{6}$ The estimates for the socioeconomic and demographic variables from the single policy specifications are very similar to those contained in Table Three.
} 
Cigarette price is found to have a negative and statistically significant impact on both smoking participation and conditional cigarette demand in all specifications. These estimates clearly show that increases in cigarette prices, which could be achieved by raising cigarette excise taxes, would lead to sharp reductions in youth cigarette smoking. Moreover, the effect of increased cigarette prices would not be limited to reductions in average daily cigarette consumption by young smokers, but would also result from substantial reductions in the probability that a youth smokes. In general, the estimated coefficients on the cigarette price variable are relatively stable in the specifications including at most one tobacco related policy variable. However, when the variable indicating that the youth resides in a state where a portion of the cigarette excise tax revenues is earmarked for other tobacco control activities is added to the model (both by itself or when the other policy variables are included), the magnitude of the price coefficient falls significantly. This is not surprising given that this indicator and cigarette prices are highly correlated since the earmarking of cigarette tax revenues accompanied several of the largest cigarette excise tax increases in recent years (most notably those in California, Massachusetts, and Michigan).

Panel A of Table Four contains the estimated price elasticities of youth cigarette demand based on the estimates from the two-part models presented in Tables Two and Three. These elasticities are based on two alternative specifications: the model excluding all other tobacco related policy measures and the model which includes these variables. The price elasticity of youth smoking participation is -0.799 in the model excluding the other tobacco related policy variables, while the conditional demand elasticity from this model is -0.651 . Thus, the total price elasticity of youth cigarette demand is -1.450 in this model. As discussed above, this 
estimate of the price effect is most subject to an omitted variables bias and may be interpreted as an upper limit for the price elasticity of youth smoking. When all of the tobacco related policy variables are included, the estimated price elasticity of youth smoking participation falls to -0.376 , with a comparable conditional demand elasticity of -0.470 . Thus, the unconditional price elasticity of youth cigarette demand in this model is -0.846 . This estimate, which is likely to be affected by the collinearity between the price and tobacco control policy variables, may be interpreted as a lower bound for the true price elasticity of youth smoking.

Substantial differences in cigarette taxes and, consequently, in cigarette prices among states may lead some youths in relatively high tax/price localities to purchase cigarettes in nearby lower tax/price localities. Failing to account for this possibility could produce biased estimates of the price elasticity of demand. As Wasserman, et al., (1991) note, this may be less of a problem when looking at youth cigarette demand than it is when estimating adult demand given that many youths are unable to drive legally and, consequently, may have only limited opportunity to engage in this type of tax evasion. Nevertheless, in an effort to control for this type of behavior, all equations were reestimated for a "restricted" sample which drops respondents living in counties within 25 miles of a state with a lower cigarette price. This is the same approach to the "butt"legging problem taken by Lewit and Coate (1982) and by Wasserman, et al., (1991). The estimated price elasticities of demand for the restricted sample are presented in Panel B of Table Four. ${ }^{7}$ The estimated elasticities for the restricted sample are higher than those for the full sample. In the model which excludes all other tobacco control

7 Coefficient estimates for the other independent variables from the two-part model for the restricted sample are generally similar to those presented in Tables Two and Three and are available upon request. 
policy variables, the estimated participation elasticity is -0.923 , while the overall elasticity of youth cigarette demand is estimated to be -1.702 . The comparable estimates of the participation and total elasticities for the full model are -0.602 and -1.254 , respectively.

These estimates indicate that substantial reductions in youth smoking would result from large increases in cigarette prices. The average of the four estimates, an unconditional elasticity of -1.313 , suggests that the effect of cigarette price increases on youth smoking is about three times as large as the impact on adult smoking. These estimates imply that approximately half of the reductions in youth smoking result from a decline in the probability that a youth will smoke, with the remainder coming from a comparable reduction in the average daily cigarette consumption of young smokers.

The estimates for the variables reflecting restrictions on smoking in public places are less consistent. When entered individually, relatively strong restrictions on smoking (those limiting smoking in private workplaces, restaurants, or retail stores) are found to have a negative and statistically significant impact on the probability of youth smoking. Less stringent restrictions (those limiting smoking in schools or any other public place), however, have little impact on youth smoking participation decisions. When all tobacco related policy measures are included, the measure reflecting the strongest restrictions on smoking, those limiting smoking in private workplaces, continues to have a negative and significant impact on the probability that a youth will smoke, while the others are generally negative, but insignificant. This is not surprising given the correlation among these different indicators. Taken together, these estimates imply that relatively strong restrictions on smoking signficantly reduce the probability that a youth will smoke. This is consistent with the findings of Wasserman, et al. (1991) for youths, Chaloupka 
and Wechsler (forthcoming) for young adults, and Evans, Farrelly, and Montgomery (1996) for adults.

However, the estimates from the conditional cigarette demand equations suggest that the relatively strong restrictions on smoking in public places and/or private workplaces have little impact on average daily cigarette consumption among young smokers. In general, the variables reflecting strong restrictions on smoking have either a positive or insignificant impact on daily cigarette consumption by smokers. The variable reflecting restrictions on smoking in schools, however, is negative and statistically signficant in both the model excluding the other policy variables and the model including all tobacco related policy variables. Of the various restrictions, the limits on smoking in school are likely to be most relevant to young smokers given the amount of time spent in school by the eighth, tenth, and twelfth grade students included in the sample.

In general, the variables reflecting the limits on the availability of tobacco products to youths have little impact on youth smoking. The coefficient on the minimum legal purchase age for cigarettes is positive and statistically significant in all models, contrary to expectations. Higher legal purchase ages were expected to increase the difficulty associated with obtaining cigarettes for underage youths and, consequently, to reduce both the probability that youths smoke as well as cigarette consumption by young smokers, similar to the reductions in youth drinking that resulted from higher minimum legal drinking ages (see, for example, the review by Grossman, et al., 1994). Similarly, the coefficients on the indicator for youths in states requiring signs indicating the minimum purchase age for cigarettes be posted where these products are sold is inconsistent across the two models for the two measures of youth smoking. 
These findings are not that surprising given the relatively limited variation in minimum purchase ages (by 1994 all states had a minimum purchase age of 18 years, with the exceptions of Alabama, Alaska and Utah where it was 19 years, and Pennsylvania where it was 21 years). Moreover, numerous studies indicate that these laws are poorly enforced and that, as a result, sales of cigarettes to underage youths are commonplace (see the 1994 Surgeon General's report for a detailed review of this literature (USDHHS, 1994)).

Similarly, the other limits on the availability of tobacco products to youth do not appear to reduce youth smoking. The coefficients on the variable reflecting restrictions on vending machine sales of tobacco products (including restrictions on vending machine placement, requirements for locking devices, and bans on vending machine sales) are positive in the four models, and significant in the two models of youth smoking participation. As with the minimum purchase ages described above, several studies suggest that these restrictions are not that well enforced and generally have little impact unless coupled with education programs, licensing, and fines (USDHHS, 1994). Moreover, young smokers are relatively unlikely to obtain cigarettes from vending machines (USDHHS, 1994), suggesting that these restrictions will have a limited impact on youth smoking at best. The coefficients for the variable reflecting limits on the distribution of free samples of cigarettes generally have a negative, albeit mostly insignificant, impact on the two measures of youth smoking. Finally, the variable capturing the state or local licensing requirements has no statistically significant effect on either measure of youth smoking. This is not surprising given that many of these licensing requirements provide little in terms of fines and/or revocation for sales to underage youth. Indeed, only a handful of the state licensing requirements even specify an enforcer (USDHHS, 1994). 
Taken together, these variables seem to suggest that limits on youth access to tobacco products are not effective in reducing youth cigarette smoking. While possible, it is more likely that it is the relatively weak enforcement of these laws that leads to their apparent ineffectiveness. For example, the relatively aggressively enforced minimum legal purchase ages for alcoholic beverages have been shown to significantly reduce youth drinking, frequency of drinking, heavy drinking, and related outcomes including drunken driving and motor vehicle accident fatalities (Grossman, et al., 1994). As states begin to comply with the Synar amendment requirements to demonstrate the effective enforcement of their laws limiting youth access to tobacco products, these policies may prove effective in reducing youth smoking.

State laws providing some form of protection for smoking appear to have little impact on the probability that a youth will smoke. However, these laws do have a positive and statistically significant impact on average daily cigarette consumption by young smokers. This may be the result of the positive climate for smoking fostered by the laws.

Finally, the variable indicating states which have earmarked a portion of their tobacco tax revenues for other tobacco control activities has a negative and statistically significant impact on both the probability that a youth will smoke and the average daily cigarette consumption of young smokers. In these states, most notably California and Massachusetts, a substantial portion of cigarette tax revenues are used for media and other educational anti-smoking efforts, much of which target youths. These results suggest that the anti-smoking activities funded by tobacco tax revenues are successful in reducing youth smoking. Given that this variable also reflects relatively large cigarette excise tax increases and, consequently, is highly correlated with cigarette prices, it may also be, in part, capturing the effects of large tax increases on youth 
cigarette demand. To some extent, this possibility is supported by the reduced magnitude of the coefficients on the cigarette price in the models when the indicator of earmarking is included.

\section{b. Socioeconomic and Demographic Variables}

Young males are found to be much less likely to smoke but to smoke more on average than young females, after controlling for other determinants of demand. Young blacks and other non-white youths are much less likely to smoke and smoke significantly less than young whites, with blacks least likely to smoke. Older youths are more likely to smoke and have higher average daily cigarette consumption than younger youths. After controlling for age, eighth and tenth grade youths are both more likely to smoke and to smoke more on average than twelfth grade youths. $^{8}$

Youths with higher real weekly incomes, either from employment or other sources, are significantly more likely to smoke and smoke more on average than youths with lower incomes. This positive relationship between income and smoking contrasts with much of the recent empirical evidence which suggests that cigarette smoking is an economically inferior behavior for adults (i.e. Wasserman, et al., 1991). The estimated overall income elasticity of youth cigarette demand is 0.294 , with the estimated income elasticity of youth smoking participation at 0.140 and the income elasticity of conditional demand at 0.154 . Similarly, youths who work more hours are much more likely to smoke and to smoke more on average than those who either

\footnotetext{
${ }^{8}$ This variable is included to control for the fact that some of the other independent variables were not collected in the surveys of eighth and tenth grade students (i.e. the marital status variable).
} 
don't work or work fewer hours.

Youths with a stronger attachment to religion, as measured by attendance at religious services, are much less likely to smoke and smoke less on average than those with little or no attachment. Smoking among youths in rural areas is significantly lower than smoking by youths in non-rural areas.

With respect to family structure, youths living in a family where both parents are present are least likely to smoke, while those who live alone are most likely to smoke. Engaged or married youths are also significantly more likely to smoke than are unattached youths. Youths with at least one sibling, however, are less likely to smoke and smoke significantly less on average than only children. Youths whose mothers worked when they were growing up are significantly more likely to smoke than youths whose mothers stayed home, with those whose mothers worked full-time most likely to smoke. Finally, youth cigarette smoking is inversely related to maternal and paternal education.

Finally, the prevalence of youth cigarette smoking is significantly higher in 1994 than in either of the other years covered by these data. However, it appears that average cigarette consumption by young smokers is falling from 1992 to 1994.

\section{Discussion}

The results described above indicate that tobacco control policies, including higher cigarette excise taxes, can be effective in reducing youth cigarette smoking. In particular, the average estimated overall price elasticity of cigarette demand of -1.313 indicates that large 
increases in cigarette excise taxes, by significantly raising price, would lead to sharp reductions in youth smoking. For example, the Clinton Administration's recent Health Security Act called for a 75 cent per pack increase in the Federal cigarette excise tax to partially finance health care reform. If this tax increase had been in effect during the period covered by these data (and had been fully passed on to smokers), overall youth smoking would have been cut in half, while the number of youth smokers would have fallen by about 25 percent. Indeed, the reductions in youth smoking would be even larger if the price increase exceeded the tax increase as has been the case for past Federal cigarette excise tax hikes (Harris, 1987; Keeler, et al., 1994; and Sung, $\mathrm{Hu}$, and Keeler, 1994).

These estimates are generally consistent with the earlier work on youth cigarette demand by Lewit and his colleagues (Lewit, Coate and Grossman, 1981); Grossman, et al., 1983). That is, the estimated overall price elasticity of youth cigarette demand is well above the consensus estimate for adults. Thus, these estimates suggest that substantial increases in cigarette excise taxes would lead to sharp reductions in youth smoking. Given that almost no smokers begin smoking after age 20 (USDHHS, 1994), large sustained increases in cigarette excise taxes are among the most effective means of achieving substantial long-run improvements in health. For example, the 75 cent tax increase described above would reduce the number of smokers ages 12 through 18 years by roughly 1.8 million. Using the relatively conservative estimate that one in four smokers dies prematurely from smoking related illnesses, these estimates imply that a real, sustained 75 cent tax hike would reduce smoking related premature deaths in this cohort by nearly 450,000. Similar, albeit smaller reductions, would occur in smoking prevalence and smoking related premature deaths in less price sensitive older age cohorts. 
In addition, the finding that youths are relatively more price sensitive than adults has important implications for the long-run revenue potential of increased cigarette excise taxes. If the demand for cigarettes by youths and young adults was as sensitive to price as that of adults (for whom the consensus estimates of the price elasticity center on -0.4), then increases in cigarette taxes would be expected to generate substantial revenues in both the short and longruns. However, if youths and young adults are much more sensitive to price, as the estimates above indicate, then sustained real increases in cigarette excise taxes will initially lead to large increases in revenues (since the smoking population is dominated by relatively older smokers). Eventually, the population will become dominated by people whose initial smoking decisions were more sensitive to price, leading to relatively larger reductions in the number of smokers. ${ }^{9}$ Consequently, the revenues associated with a relatively large cigarette tax increase would rise sharply in the short run, but would eventually decline over time. Nevertheless, given current cigarette taxes and prices, the long-run revenue maximizing level of the tax is well above its

${ }^{9}$ The Congressional Research Service (CRS, 1994) provides a useful definition of the longrun in its evaluation of the long run revenue effects of higher cigarette excise taxes. It defines the long run as 69 years, which allows the 12 to 80 year old population (which includes nearly all regular smokers) to fully adjust to changes in cigarette taxes.

In addition, the long-run revenue implications of higher cigarette taxes is complicated by the addictive nature of cigarette smoking. Recent econometric studies accounting for the addictive aspects of cigarette consumption (Becker, Grossman, and Murphy, 1994; Chaloupka, 1991) estimate a long run price elasticity about double their short run estimates. This is due to the cumulative effect of a sustained increase in price on cigarette demand. If there is a permanent increase in cigarette prices, then cigarette consumption in the current and all future periods falls. However, given the addictive nature of consumption, future consumption also falls as a result of the drop in current consumption. The long run, in this sense, is defined as the period when consumption at all times fully responds to a permanent change in price (similar to the 69 years used by the CRS). 
current level. ${ }^{10}$

Additionally, the estimates presented above indicate that stronger restrictions on smoking in public places lead to significant reductions in the prevalence of smoking among youths. Further limits on smoking in schools are also found to be effective in reducing average daily cigarette consumption among young smokers. However, limits on youth access to tobacco products appear to have little impact on youth cigarette smoking. This is most likely the result of the relatively weak enforcement of these laws. As the enforcement requirements of the Synar amendment are implemented, the limits on youth access may prove effective in reducing youth smoking.

${ }^{10}$ For example, based on the Becker, Grossman, and Murphy (1994) and Chaloupka (1991) estimates, Grossman (1993) predicts that a Federal cigarette excise tax of $\$ 1.26$ would have maximize revenues. Similarly, Merriman (1994) concludes that, at least in 1985, cigarette taxes in every state were well below their revenue maximizing levels. 


\section{References}

Altman, D.G., L. Rasenick-Douss, V. Foster, and J.B. Tye, "Sustained Efforts of an Educational Program to Reduce Sales of Cigarettes to Minors," American Journal of Public Health, 81: 891-3, 1991.

Becker, G.S., and K.M. Murphy, "A Theory of Rational Addiction," Journal of Political Economy, 96: 675-700, 1988.

Becker, G.S., M. Grossman, and K.M. Murphy, "An Empirical Analysis of Cigarette Addiction," American Economic Review, 84: 396-418, 1994.

Centers for Disease Control and Prevention, "Surveillance for Selected Tobacco-Use Behaviors United States, 1900-1994," Morbidity and Mortality Weekly Report. CDC Surveillance Series, Volume 43, November 18, 1994.

Chaloupka, F.J., "Rational Addictive Behavior and Cigarette Smoking," Journal of Political Economy, 99: 722-42, 1991.

Chaloupka, F.J., "Clean Indoor Air Laws, Addition, and Cigarette Smoking," Applied Economics, 24: 193-205, 1992.

Chaloupka, F.J., and H. Saffer, "Clean Indoor Air Laws and the Demand for Cigarettes," Contemporary Policy Issues, 10: 72-83, 1992.

Chaloupka, F.J., and H. Wechsler, "Price, Tobacco Control Policies, and Smoking Among Young Adults, " National Bureau of Economic Research Working Paper Number 5012, February, 1995.

Chaloupka, F.J., and H. Wechsler, "Price, Tobacco Control Policies, and Smoking Among Young Adults," Journal of Health Economics, forthcoming.

Coalition on Smoking OR Health, State Legislated Actions on Tobacco Issues, Washington, D.C.: Coalition on Smoking OR Health, various years.

Congressional Research Service, Cigarette Taxes to Fund Health Care Reform: An Economic Analysis, Washington D.C.: Library of Congress, 1994.

Cragg, J.G., "Some Statistical Models for Limited Dependent Variables with Application to the Demand for Durable Goods," Econometrica, 39, No. 5, 1971.

DiFranza, J.R., B.D. Norwood, D.W. Garner, and J.B. Tye, "Legislative Efforts to Protect Children From Tobacco," Journal of the American Medical Association, 257: 3387-9, 1987. 
Evans, W.N., and M.C. Farrelly, "The Compensating Behavior of Smokers: Taxes, Tar and Nicotine," working paper, Department of Economics, University of Maryland, 1995.

Evans, W.N., M.C. Farrelly, and E. Montgomery, "Do Workplace Smoking Bans Reduce Smoking?" working paper, Department of Economics, University of Maryland, 1996.

Forster, J.L., M.E. Hourigan, and S. Kelder, "Locking Devices on Cigarette Vending Machines: Evaluation of a City Ordinance," American Journal of Public Health, 82: 1217-9, 1992.

General Accounting Office, Teenage Smoking: Higher Excise Tax Should Significantly Reduce the Number of Smokers, Washington D.C.: General Accounting Office, 1989.

Grossman, M., "Editorial: The Demand for Cigarettes," Journal of Health Economics, 10: 101-3, 1991.

Grossman, M., "For Best Revenue, Tax Cigarettes \$1.26," New York Times, June 18, 1993.

Grossman, M., D. Coate, E.M. Lewit, and R.A. Shakotko, "Economic and Other Factors in Youth Smoking," Final Report, National Science Foundation, 1983.

Grossman, M., F.J. Chaloupka, H. Saffer, and A. Laixuthai, " Alcohol Price Policy and Youths: A Summary of Economic Research," (with Michael Grossman, Henry Saffer, and Adit Laixuthai), Journal of Research on Adolescence, 4, No. 2: 347-364, 1994.

Harris, J.E., "The 1983 Increase in the Federal Cigarette Excise Tax." In Tax Policy and the Economy, volume 1, edited by Lawrence H. Summers. Cambridge, MA: MIT Press (for the National Bureau of Economic Research), 1987.

Institute of Medicine, Growing Up Tobacco Free: Preventing Nicotine Addiction in Children and Youths, Washington D.C.: National Academy Press, 1994.

Jason, L.A., P.Y. Ji, M.D. Anes, and S.H. Birkhead, "Active Enforcement of Cigarette Control Laws in the Prevention of Cigarette Sales to Minors, Journal of the American Medical Association, 266: 3159-61, 1991.

Johnston, L.D., P.M. O'Malley, and J.D. Bachman, National Survey Results from the Monitoring the Future Study, 1975-1992. NIH Publication Number 93-3597/98. Washington, D.C.: U.S. Government Printing Office, 1993.

Keeler, T.E., T.W. Hu, P.G. Barnett, W.G. Manning, and H. Sung, "Tobacco Taxation, Demand, and Oligopoly Behavior: Analysis and Estimation with State Panel Data," Working Paper, Institute of Business and Economic Research, University of California, Berkeley, 1994. 
Lewit, E.M., and D. Coate, "The Potential for Using Excise Taxes to Reduce Smoking," Journal of Health Economics, 1: 121-45, 1982.

Lewit, E.M., D. Coate, and M. Grossman, "The Effects of Government Regulations on Teenage Smoking," Journal of Law and Economics, 24: 545-69, 1981.

Merriman, D., "Do Cigarette Excise Tax Rates Maximize Revenue?" Economic Inquiry, 32: 419-28, 1994.

National Cancer Institute, The Impact of Cigarette Excise Taxes on Smoking Among Children and Adults: Summary Report of a National Cancer Institute Expert Panel, Bethesda, Maryland: National Cancer Institute, Division of Cancer Prevention and Control, Cancer Control Science Program, 1993a.

National Cancer Institute, Major Local Tobacco Control Ordinances in the United States, Monograph 3, Bethesda, Maryland: U.S. Department of Health and Human Services, Public Health Service, National Institutes of Health, 1993b.

Sung, H.Y, T.W. Hu, and T.E. Keeler, "Cigarette Taxation and Demand: An Empirical Model," Contemporary Economic Policy, forthcoming.

Tobacco Institute, The Tax Burden on Tobacco, Washington D.C.: Tobacco Institute, 1995.

U.S. Department of Health and Human Services, The Health Consequences of Smoking: Cancer and Chronic Lung Disease in the Workplace. A Report of the Surgeon General. Rockville, Maryland: U.S. Department of Health and Human Services, Public Health Service, Centers for Disease Control, Center for Chronic Disease Prevention and Health Promotion, Office on Smoking and Health, 1985.

U.S. Department of Health and Human Services, The Health Consequences of Smoking: Nicotine Addiction. A Report of the Surgeon General. Rockville, Maryland: U.S. Department of Health and Human Services, Public Health Service, Centers for Disease Control, Center for Chronic Disease Prevention and Health Promotion, Office on Smoking and Health, 1988.

U.S. Department of Health and Human Services, Reducing the Health Consequences of Smoking: 25 Years of Progress. A Report of the Surgeon General. Rockville, Maryland: U.S. Department of Health and Human Services, Public Health Service, Centers for Disease Control, Center for Chronic Disease Prevention and Health Promotion, Office on Smoking and Health, 1989.

U.S. Department of Health and Human Services, Preventing Tobacco Use Among Young People: A Report of the Surgeon General, Atlanta, Georgia: U.S. Department of Health and Human Services, Public Health Service, Centers for Disease Control and Prevention, National Center for Chronic Disease Prevention and Health Promotion, Office on Smoking and Health, 
1994.

U.S. Department of Health and Human Services, The Context for Change: The Efficacy of Interventions for Smoking Prevention and Control. A Report of the Surgeon General, Atlanta, Georgia: U.S. Department of Health and Human Services, Public Health Service, Centers for Disease Control and Prevention, National Center for Chronic Disease Prevention and Health Promotion, Office on Smoking and Health, forthcoming.

Warner, K.E., "Consumption Impacts of a Change in the Federal Cigarette Excise Tax," in Smoking Behavior and Policy Conference Series: The Cigarette Excise Tax, Cambridge, MA: Institute for the Study of Smoking Behavior and Policy, 1985.

Wasserman, J., W.G. Manning, J.P. Newhouse, and J.D. Winkler, "The Effects of Excise Taxes and Regulations on Cigarette Smoking, " Journal of Health Economics, 10: 43-64, 1991. 
Table One

Variable Definitions and Descriptive Statistics

\begin{tabular}{|c|c|}
\hline Variable & Definition, Mean $(\mu)$, and Standard Deviation $(\sigma)$ \\
\hline $\begin{array}{l}\text { Smoking } \\
\text { Participation }\end{array}$ & $\begin{array}{l}\text { Dichotmous indicator equal to one if youth reports smoking in the } \\
\text { past month, equal to zero otherwise. } \mu=0.229, \sigma=0.420\end{array}$ \\
\hline $\begin{array}{l}\text { Cigarette } \\
\text { Consumption by } \\
\text { Smokers }\end{array}$ & $\begin{array}{l}\text { Natural logarithm of average daily cigarette consumption, smokers } \\
\text { only. } \mu=0.744, \sigma=1.439\end{array}$ \\
\hline Real Cigarette Price & $\begin{array}{l}\text { Average price of a pack of twenty cigarettes, in cents, deflated by } \\
\text { the national Consumer Price Index, 1984-84=1.00. } \mu=124.756 \text {, } \\
\sigma=13.564\end{array}$ \\
\hline $\begin{array}{l}\text { Workplace Smoking } \\
\text { Restrictions }\end{array}$ & $\begin{array}{l}\text { Fraction of population in youth's county of residence subject to } \\
\text { state or local restrictions on smoking in private workplaces. } \\
\mu=0.531, \sigma=0.469\end{array}$ \\
\hline $\begin{array}{l}\text { Restaurant Smoking } \\
\text { Restrictions }\end{array}$ & $\begin{array}{l}\text { Fraction of population in youth's county of residence subject to } \\
\text { state or local restrictions on smoking in restaurants. } \mu=0.740 \text {, } \\
\sigma=0.417\end{array}$ \\
\hline $\begin{array}{l}\text { Retail Smoking } \\
\text { Restrictions }\end{array}$ & $\begin{array}{l}\text { Fraction of population in youth's county of residence subject to } \\
\text { state or local restrictions on smoking in retail stores. } \mu=0.644 \text {, } \\
\sigma=0.461\end{array}$ \\
\hline $\begin{array}{l}\text { School Smoking } \\
\text { Restrictions }\end{array}$ & $\begin{array}{l}\text { Fraction of population in youth's county of residence subject to } \\
\text { state or local restrictions on smoking in schools. } \mu=0.912 \text {, } \\
\sigma=0.281\end{array}$ \\
\hline $\begin{array}{l}\text { Other Smoking } \\
\text { Restrictions }\end{array}$ & $\begin{array}{l}\text { Fraction of population in youth's county of residence subject to } \\
\text { any state or local restrictions on smoking, other than in private } \\
\text { workplaces, restaurants, retail stores, or schools. } \mu=0.927 \text {, } \\
\sigma=0.258\end{array}$ \\
\hline $\begin{array}{l}\text { Minimum Purchase } \\
\text { Age }\end{array}$ & $\begin{array}{l}\text { State minimum legal purchase age, in years, for tobacco products. } \\
\mu=18.161, \sigma=0.684\end{array}$ \\
\hline $\begin{array}{l}\text { Minimum Purchase } \\
\text { Age Sign Required }\end{array}$ & $\begin{array}{l}\text { Dichotomous indicator equal to one if the youth resides in a state } \\
\text { requiring signs reflecting the minimum purchase age for tobacco } \\
\text { products be posted where these products are sold, equal to zero } \\
\text { otherwise. } \mu=0.747, \sigma=0.435\end{array}$ \\
\hline
\end{tabular}




\begin{tabular}{|c|c|}
\hline Variable & Definition, Mean $(\mu)$, and Standard Deviation $(\sigma)$ \\
\hline $\begin{array}{l}\text { Vending Machine } \\
\text { Restrictions }\end{array}$ & $\begin{array}{l}\text { Fraction of population in youth's county of residence subject to } \\
\text { any state or local restrictions on the sale of tobacco products } \\
\text { through vending machines. } \mu=0.748, \sigma=0.422\end{array}$ \\
\hline $\begin{array}{l}\text { Limits on Free } \\
\text { Sample Distribution }\end{array}$ & $\begin{array}{l}\text { Fraction of population in youth's county of residence subject to } \\
\text { any state or local restrictions on the distribution of free samples of } \\
\text { tobacco products. } \quad \mu==0.566, \sigma=0.491\end{array}$ \\
\hline $\begin{array}{l}\text { Tobacco Licensing } \\
\text { Provisions }\end{array}$ & $\begin{array}{l}\text { Fraction of population in youth's county of residence in which a } \\
\text { license is required to sell tobacco products. } \mu=0.922, \sigma=0.268\end{array}$ \\
\hline $\begin{array}{l}\text { Cigarette Tax } \\
\text { Earmarking }\end{array}$ & $\begin{array}{l}\text { Dichotomous indicator equal to one if the youth resides in a state } \\
\text { earmarking a portion of cigarette tax revenues for other tobacco } \\
\text { control activities, equal to zero otherwise. } \mu=0.158, \sigma=0.365\end{array}$ \\
\hline Smoking Protection & $\begin{array}{l}\text { Dichotomous indicator equal to one if the youth resides in a state } \\
\text { with any smoking protection legislation, equal to zero otherwise. } \\
\mu=0.476, \sigma=0.499\end{array}$ \\
\hline Male & $\begin{array}{l}\text { Dichotomous indicator equal to one for males and zero for } \\
\text { females. } \mu=0.481, \sigma=0.500\end{array}$ \\
\hline Black & $\begin{array}{l}\text { Dichotomous indicator equal to one for blacks and zero otherwise. } \\
\mu=0.116, \sigma=0.321\end{array}$ \\
\hline Other Race & $\begin{array}{l}\text { Dichotomous indicator equal to one for individuals who are not } \\
\text { black or white and zero otherwise. } \mu=0.208, \sigma=0.406\end{array}$ \\
\hline Age & Age, in years. $\mu=16.100, \sigma=1.823$ \\
\hline $\begin{array}{l}\text { Infrequent Religious } \\
\text { Attendence }\end{array}$ & $\begin{array}{l}\text { Dichotomous indicator equal to one for youths who attend } \\
\text { religious services infrequently and zero otherwise. } \mu=0.486 \text {, } \\
\sigma=0.500\end{array}$ \\
\hline $\begin{array}{l}\text { Frequent Religious } \\
\text { Attendence }\end{array}$ & $\begin{array}{l}\text { Dichotomous indicator equal to one for youths who attend religous } \\
\text { services frequently and zero otherwise. } \mu=0.383, \sigma=0.486\end{array}$ \\
\hline Rural & $\begin{array}{l}\text { Dichotomous indicator equal to one for youths in rural } \\
\text { communities and zero otherwise. } \mu=0.269, \sigma=0.444\end{array}$ \\
\hline Live Alone & $\begin{array}{l}\text { Dichotomous indicator equal to one for youths who live alone and } \\
\text { zero otherwise. } \mu=0.004, \sigma=0.062\end{array}$ \\
\hline Father Only & $\begin{array}{l}\text { Dichotomous indicator equal to one for youths in families with the } \\
\text { father the only parent present and zero otherwise. } \mu=0.034 \text {, } \\
\sigma=0.181\end{array}$ \\
\hline
\end{tabular}




\begin{tabular}{|c|c|}
\hline Variable & Definition, Mean $(\mu)$, and Standard Deviation $(\sigma)$ \\
\hline Mother Only & $\begin{array}{l}\text { Dichotomous indicator equal to one for youths in families with the } \\
\text { mother the only parent present and zero otherwise. } \mu=0.155 \text {, } \\
\sigma=0.362\end{array}$ \\
\hline $\begin{array}{l}\text { Other Family } \\
\text { Structure }\end{array}$ & $\begin{array}{l}\text { Dichotomous indicator equal to one for youths in families with } \\
\text { neither parent present and zero otherwise. } \mu=0.029, \sigma=0.169\end{array}$ \\
\hline Siblings & $\begin{array}{l}\text { Dichotomous indicator equal to one for youths with at least one } \\
\text { sibling and zero otherwise. } \mu=0.762, \sigma=0.426\end{array}$ \\
\hline $\begin{array}{l}\text { Father Less Than } \\
\text { High School } \\
\text { Graduate }\end{array}$ & $\begin{array}{l}\text { Dichotomous indicator equal to one for youths with fathers who } \\
\text { did not graduate from high school and zero otherwise. } \mu=0.135 \text {, } \\
\sigma=0.345\end{array}$ \\
\hline $\begin{array}{l}\text { Father More Than } \\
\text { High School } \\
\text { Graduate }\end{array}$ & $\begin{array}{l}\text { Dichotomous indicator equal to one for youth with fathers who } \\
\text { have more than a high school education and zero otherwise. } \\
\mu=0.576, \sigma=0.494\end{array}$ \\
\hline $\begin{array}{l}\text { Mother Less Than } \\
\text { High School } \\
\text { Graduate }\end{array}$ & $\begin{array}{l}\text { Dichotomous indicator equal to one for youths with mothers who } \\
\text { did not graduate from high school and zero otherwise. } \mu=0.123 \text {, } \\
\sigma=0.328\end{array}$ \\
\hline $\begin{array}{l}\text { Mother More Than } \\
\text { High School } \\
\text { Graduate }\end{array}$ & $\begin{array}{l}\text { Dichotomous indicator equal to one for youth with mothers who } \\
\text { have more than a high school education and zero otherwise. } \\
\mu=0.551, \sigma=0.497\end{array}$ \\
\hline Not Single & $\begin{array}{l}\text { Dichotomous indicator equal to one for youths who are either } \\
\text { married or engaged and zero otherwise. } \mu=0.023, \sigma=0.151\end{array}$ \\
\hline $\begin{array}{l}\text { Mother Worked } \\
\text { Part-time }\end{array}$ & $\begin{array}{l}\text { Dichotomous indicator equal to one for youths whose mothers } \\
\text { worked part-time while they were growing up and zero otherwise. } \\
\mu=0.218, \sigma=0.413\end{array}$ \\
\hline $\begin{array}{l}\text { Mother Worked } \\
\text { Full-time }\end{array}$ & $\begin{array}{l}\text { Dichotomous indicator equal to one for youths whose mothers } \\
\text { worked full-time while they were growing up and zero otherwise. } \\
\mu=0.578, \sigma=0.494\end{array}$ \\
\hline $\begin{array}{l}\text { Average Hours } \\
\text { Worked }\end{array}$ & Average hours worked weekly for pay. $\mu=7.025, \sigma=9.641$ \\
\hline $\begin{array}{l}\text { Real Weekly } \\
\text { Income }\end{array}$ & $\begin{array}{l}\text { Average weekly income, in dollars, from employment and other } \\
\text { sources, deflated by the national Consumer Price Index, 1982- } \\
84=1 . \quad \mu=31.533, \sigma=35.184\end{array}$ \\
\hline Grade 8 or 10 & $\begin{array}{l}\text { Dichotomous indicator equal to one for youths surveyed in the } \\
\text { eighth/tenth grade survey and zero otherwise. } \mu=0.689, \sigma=0.463\end{array}$ \\
\hline
\end{tabular}




\begin{tabular}{||l|l||}
\hline Variable & Definition, Mean $(\mu)$, and Standard Deviation $(\sigma)$ \\
\hline \hline Year $=1993$ & $\begin{array}{l}\text { Dichotomous indicator equal to one for youths surveyed in } 1993 \\
\text { and zero otherwise. } \quad \mu=0.339, \mu=0.473\end{array}$ \\
\hline Year $=1994$ & $\begin{array}{l}\text { Dichotomous indicator equal to one for youths surveyed in } 1994 \\
\text { and zero otherwise. } \quad \mu=0.336, \sigma=0.472\end{array}$ \\
\hline
\end{tabular}

Note to Table One: Sample size is 110,717 . 
Table Two

Estimates of Two-Part Models of Youth Cigarette Demand

Single Policy Models

\begin{tabular}{|c|c|c|c|c|}
\hline & Smoking & Participation & Cigarettes & per day \\
\hline Policy Variable & $\begin{array}{c}\text { Policy } \\
\text { Variable }\end{array}$ & $\begin{array}{l}\text { Cigarette } \\
\text { Price }\end{array}$ & $\begin{array}{c}\text { Policy } \\
\text { Variable }\end{array}$ & $\begin{array}{l}\text { Cigarette } \\
\text { Price }\end{array}$ \\
\hline Cigarette Price Only & & $\begin{array}{c}-0.005 \\
(-14.32)\end{array}$ & & $\begin{array}{l}-0.005 \\
(-7.59)\end{array}$ \\
\hline $\begin{array}{l}\text { Workplace Smoking } \\
\text { Restrictions }\end{array}$ & $\begin{array}{l}-0.036 \\
(-3.46)\end{array}$ & $\begin{array}{c}-0.004 \\
(-11.38)\end{array}$ & $\begin{array}{l}0.047 \\
(2.29)\end{array}$ & $\begin{array}{l}-0.006 \\
(-7.82)\end{array}$ \\
\hline $\begin{array}{l}\text { Restaurant Smoking } \\
\text { Restrictions }\end{array}$ & $\begin{array}{l}-0.035 \\
(-2.74)\end{array}$ & $\begin{array}{c}-0.004 \\
(-10.35)\end{array}$ & $\begin{array}{l}0.070 \\
(2.76)\end{array}$ & $\begin{array}{l}-0.007 \\
(-7.83)\end{array}$ \\
\hline Retail Smoking Restrictions & $\begin{array}{l}-0.063 \\
(-5.32)\end{array}$ & $\begin{array}{l}-0.004 \\
(-8.48)\end{array}$ & $\begin{array}{l}-0.002 \\
(-0.10)\end{array}$ & $\begin{array}{l}-0.005 \\
(-6.08)\end{array}$ \\
\hline School Smoking Restrictions & $\begin{array}{l}0.009 \\
(0.57)\end{array}$ & $\begin{array}{c}-0.005 \\
(-14.05)\end{array}$ & $\begin{array}{l}-0.068 \\
(-2.10)\end{array}$ & $\begin{array}{l}-0.005 \\
(-6.90)\end{array}$ \\
\hline Other Smoking Restrictions & $\begin{array}{l}-0.018 \\
(-0.97)\end{array}$ & $\begin{array}{c}-0.005 \\
(-13.08)\end{array}$ & $\begin{array}{l}-0.046 \\
(-1.24)\end{array}$ & $\begin{array}{l}-0.005 \\
(-6.61)\end{array}$ \\
\hline Minimum Legal Purchase Age & $\begin{array}{l}0.018 \\
(2.88)\end{array}$ & $\begin{array}{c}-0.005 \\
(-14.00)\end{array}$ & $\begin{array}{l}0.035 \\
(2.94)\end{array}$ & $\begin{array}{l}-0.005 \\
(-7.29)\end{array}$ \\
\hline $\begin{array}{l}\text { Minimum Purchase Age Sign } \\
\text { Required }\end{array}$ & $\begin{array}{l}-0.025 \\
(-2.41)\end{array}$ & $\begin{array}{c}-0.005 \\
(-13.58)\end{array}$ & $\begin{array}{l}-0.004 \\
(-0.19)\end{array}$ & $\begin{array}{l}-0.005 \\
(-7.42)\end{array}$ \\
\hline Vending Machine Restrictions & $\begin{array}{l}0.028 \\
(2.57)\end{array}$ & $\begin{array}{l}-0.005 \\
(-14.55)\end{array}$ & $\begin{array}{l}0.005 \\
(0.23)\end{array}$ & $\begin{array}{l}-0.005 \\
(-7.48)\end{array}$ \\
\hline $\begin{array}{l}\text { Limits on Free Sample } \\
\text { Distribution }\end{array}$ & $\begin{array}{l}-0.024 \\
(-2.67)\end{array}$ & $\begin{array}{c}-0.005 \\
(-13.58)\end{array}$ & $\begin{array}{l}0.006 \\
(0.35)\end{array}$ & $\begin{array}{l}-0.005 \\
(-7.53)\end{array}$ \\
\hline Tobacco Licensing Provisions & $\begin{array}{l}0.013 \\
(0.79)\end{array}$ & $\begin{array}{c}-0.005 \\
(-14.05)\end{array}$ & $\begin{array}{l}-0.0002 \\
(-0.01)\end{array}$ & $\begin{array}{l}-0.005 \\
(-7.35)\end{array}$ \\
\hline Cigarette Tax Earmarking & $\begin{array}{l}-0.102 \\
(-7.59)\end{array}$ & $\begin{array}{c}-0.004 \\
(-10.97)\end{array}$ & $\begin{array}{l}-0.110 \\
(-4.08)\end{array}$ & $\begin{array}{l}-0.004 \\
(-5.98)\end{array}$ \\
\hline Smoking Protection & $\begin{array}{l}-0.002 \\
(-0.19)\end{array}$ & $\begin{array}{c}-0.005 \\
(-14.13)\end{array}$ & $\begin{array}{l}0.050 \\
(2.87)\end{array}$ & $\begin{array}{l}-0.005 \\
(-7.04)\end{array}$ \\
\hline
\end{tabular}


Notes to Table Two: t-ratios are in parentheses. Each row represents a different specification which, in addition to price and the tobacco related policy noted in that row, includes: an intercept, indicators of gender, race, age, religiosity, rural residence, family structure, parental education, maternal work status, grade and year, and continuous measures of average hours worked and real income. The results for these variables are available upon request. 
Table Three

Estimates from Two-Part Models of Youth Cigarette Demand

Full Model

\begin{tabular}{|c|c|c|}
\hline Independent Variables & Smoking Participation & $\begin{array}{c}\text { Cigarette consumption } \\
\text { by smokers }\end{array}$ \\
\hline Intercept & $\begin{array}{l}-2.306 \\
(-10.06) \\
\end{array}$ & $\begin{array}{l}-1.635 \\
(-6.27)\end{array}$ \\
\hline Real Cigarette Price & $\begin{array}{l}-0.002 \\
(-4.66)\end{array}$ & $\begin{array}{l}-0.004 \\
(-3.80)\end{array}$ \\
\hline Workplace Smoking Restrictions & $\begin{array}{l}-0.054 \\
(-3.87) \\
\end{array}$ & $\begin{array}{l}-0.016 \\
(-0.57) \\
\end{array}$ \\
\hline Restaurant Smoking Restrictions & $\begin{array}{l}-0.003 \\
(-0.13)\end{array}$ & $\begin{array}{l}0.117 \\
(2.82) \\
\end{array}$ \\
\hline Retail Smoking Restrictions & $\begin{array}{l}-0.023 \\
(-1.07)\end{array}$ & $\begin{array}{l}-0.025 \\
(-0.60)\end{array}$ \\
\hline School Smoking Restrictions & $\begin{array}{l}0.024 \\
(1.32)\end{array}$ & $\begin{array}{l}-0.093 \\
(-2.62)\end{array}$ \\
\hline Other Smoking Restrictions & $\begin{array}{l}-0.030 \\
(-1.39) \\
\end{array}$ & $\begin{array}{l}-0.099 \\
(-2.30) \\
\end{array}$ \\
\hline Minimum Legal Purchase Age & $\begin{array}{l}0.038 \\
(3.50) \\
\end{array}$ & $\begin{array}{l}0.058 \\
(2.72) \\
\end{array}$ \\
\hline Minimum Purchase Age Sign Required & $\begin{array}{l}-0.014 \\
(-1.11) \\
\end{array}$ & $\begin{array}{l}0.028 \\
(2.53) \\
\end{array}$ \\
\hline Vending Maching Restrictions & $\begin{array}{l}0.029 \\
(2.05)\end{array}$ & $\begin{array}{l}0.010 \\
(0.35)\end{array}$ \\
\hline Limits on Free Sample Distribution & $\begin{array}{l}-0.010 \\
(-0.99)\end{array}$ & $\begin{array}{l}-0.032 \\
(-1.58)\end{array}$ \\
\hline Tobacco Licensing Provisions & $\begin{array}{l}0.023 \\
(1.29) \\
\end{array}$ & $\begin{array}{l}-0.008 \\
(-0.24) \\
\end{array}$ \\
\hline Cigarette Tax Earmarking & $\begin{array}{l}-0.110 \\
(-6.57) \\
\end{array}$ & $\begin{array}{l}-0.117 \\
(-3.49) \\
\end{array}$ \\
\hline Smoking Protection & $\begin{array}{l}0.007 \\
(0.59) \\
\end{array}$ & $\begin{array}{l}0.056 \\
(2.53) \\
\end{array}$ \\
\hline Male & $\begin{array}{l}-0.053 \\
(-5.97)\end{array}$ & $\begin{array}{l}0.038 \\
(2.61)\end{array}$ \\
\hline
\end{tabular}




\begin{tabular}{|c|c|c|}
\hline Independent Variables & Smoking Participation & $\begin{array}{c}\text { Cigarette consumption } \\
\text { by smokers }\end{array}$ \\
\hline Black & $\begin{array}{c}-0.866 \\
(-47.26) \\
\end{array}$ & $\begin{array}{r}-0.715 \\
(-15.92) \\
\end{array}$ \\
\hline Other Race & $\begin{array}{c}-0.122 \\
(-10.82) \\
\end{array}$ & $\begin{array}{l}-0.154 \\
(-6.93) \\
\end{array}$ \\
\hline Age & $\begin{array}{c}0.081 \\
(18.30)\end{array}$ & $\begin{array}{c}0.125 \\
(13.64) \\
\end{array}$ \\
\hline Infrequent Religious Attendence & $\begin{array}{c}-0.154 \\
(-12.16) \\
\end{array}$ & $\begin{array}{c}-0.386 \\
(-16.72) \\
\end{array}$ \\
\hline Frequent Religious Attendence & $\begin{array}{r}-0.477 \\
(-34.77) \\
\end{array}$ & $\begin{array}{c}-0.633 \\
(-23.70)\end{array}$ \\
\hline Rural & $\begin{array}{l}-0.026 \\
(-2.51) \\
\end{array}$ & $\begin{array}{l}-0.042 \\
(-2.10) \\
\end{array}$ \\
\hline Live Alone & $\begin{array}{l}0.338 \\
(5.27) \\
\end{array}$ & $\begin{array}{l}0.643 \\
(6.21) \\
\end{array}$ \\
\hline Father Only & $\begin{array}{l}0.208 \\
(9.08) \\
\end{array}$ & $\begin{array}{l}0.228 \\
(5.49) \\
\end{array}$ \\
\hline Mother Only & $\begin{array}{l}0.118 \\
(9.42) \\
\end{array}$ & $\begin{array}{l}0.154 \\
(6.43) \\
\end{array}$ \\
\hline Other Family Structure & $\begin{array}{l}0.177 \\
(6.76) \\
\end{array}$ & $\begin{array}{l}0.327 \\
(6.86) \\
\end{array}$ \\
\hline Siblings & $\begin{array}{l}-0.072 \\
(-6.76) \\
\end{array}$ & $\begin{array}{l}-0.061 \\
(-3.01)\end{array}$ \\
\hline Father Less Than High School Graduate & $\begin{array}{l}0.072 \\
(4.82) \\
\end{array}$ & $\begin{array}{l}0.116 \\
(4.17) \\
\end{array}$ \\
\hline $\begin{array}{l}\text { Father More Than High School } \\
\text { Graduate }\end{array}$ & $\begin{array}{l}-0.029 \\
(-2.68)\end{array}$ & $\begin{array}{l}-0.115 \\
(-5.46)\end{array}$ \\
\hline $\begin{array}{l}\text { Mother Less Than High School } \\
\text { Graduate }\end{array}$ & $\begin{array}{l}0.051 \\
(3.37) \\
\end{array}$ & $\begin{array}{l}0.042 \\
(1.48) \\
\end{array}$ \\
\hline $\begin{array}{l}\text { Mother More Than High School } \\
\text { Graduate }\end{array}$ & $\begin{array}{l}-0.025 \\
(-2.40) \\
\end{array}$ & $\begin{array}{l}-0.081 \\
(-4.02) \\
\end{array}$ \\
\hline Not Single & $\begin{array}{l}0.047 \\
(2.94) \\
\end{array}$ & $\begin{array}{l}0.397 \\
(8.27)\end{array}$ \\
\hline Mother Worked Part-time & $\begin{array}{l}0.026 \\
(1.97)\end{array}$ & $\begin{array}{l}-0.054 \\
(-4.02)\end{array}$ \\
\hline
\end{tabular}




\begin{tabular}{||l|c|c||}
\hline Independent Variables & Smoking Participation & $\begin{array}{c}\text { Cigarette consumption } \\
\text { by smokers }\end{array}$ \\
\hline \hline & 0.052 & 0.029 \\
Mother Worked Full-time & $(4.59)$ & $(1.28)$ \\
\hline & 0.006 & 0.007 \\
Average Hours Worked & $(9.66)$ & $(6.09)$ \\
\hline & 0.004 & 0.004 \\
Real Weekly Income & $(22.21)$ & $(13.00)$ \\
\hline & 0.131 & 0.230 \\
Grade 8 or 10 & $(7.68)$ & $(6.97)$ \\
\hline & 0.002 & -0.030 \\
Year $=1993$ & $(0.15)$ & $(-1.29)$ \\
\hline & 0.051 & -0.070 \\
Year $=1994$ & $(3.57)$ & $(-2.48)$ \\
\hline
\end{tabular}

Note to Table Three: $\mathrm{t}$-ratios are in parentheses. 
Table Four

Estimated Price Elasticities of Youth Cigarette Demand

Panel A: Full Sample

\begin{tabular}{||l|c|c|c||}
\hline \hline & $\begin{array}{c}\text { Smoking } \\
\text { Participation }\end{array}$ & $\begin{array}{c}\text { Cigarette } \\
\text { Consumption by } \\
\text { Smokers }\end{array}$ & $\begin{array}{c}\text { Total Price } \\
\text { Elasticity of Youth } \\
\text { Cigarette Demand }\end{array}$ \\
\hline Price Only Model & -0.799 & -0.651 & -1.450 \\
\hline Full Model & -0.376 & -0.470 & -0.846 \\
\hline
\end{tabular}

Panel B: Restricted Sample

\begin{tabular}{||l|c|c|c||}
\hline \hline & $\begin{array}{c}\text { Smoking } \\
\text { Participation }\end{array}$ & $\begin{array}{c}\text { Cigarette } \\
\text { Consumption by } \\
\text { Smokers }\end{array}$ & $\begin{array}{c}\text { Total Price } \\
\text { Elasticity of Youth } \\
\text { Cigarette Demand }\end{array}$ \\
\hline Price Only Model & -0.923 & -0.779 & -1.702 \\
\hline Full Model & -0.602 & -0.652 & -1.254 \\
\hline
\end{tabular}

Note to Table Four: The price elasticities for the restricted sample are based on estimates of models comparable to those contained in Tables Two and Three. The estimates for these models are available upon request. The sample size for the restricted sample is 75,090 respondents. 